\title{
INVESTIGATING INCOME SMOOTHING: EMPIRICAL EVIDENCE FROM VIETNAM'S LISTED COMPANIES
}

\author{
PHUNG ANH THU \\ Nguyen Tat Thanh University, Vietnam - phunganhthu1990@gmail.com
}

NGUYEN VINH KHUONG

University of Economics and Law-Vietnam National University HCMC - khuongnguyenktkt@gmail.com

(Received: April 16, 2017; Revised: September 29, 2017; Accepted: October 31, 2017)

\begin{abstract}
The income smoothing is a dimension of the accounts manipulation theme that has been attracting a great attention in the accounting literature. A goal of manipulation is widely ascribed to managers who wants income smoothing. The author has tried to investigate income smoothing at listed companies on the Stock Exchange. For this purpose, we chose a stratified random sample of 285 companies from formula listed companies on Vietnam Stock Exchange. We carried the mechanism for smooth and non-smoothing companies Eckel model (coefficient of variation of a distribution of profits to sales). We have compared 111 smoothing companies and 174 non-smoothing companies. The study results suggest that the Eckel index is suitable for the Vietnam stock market and show a slight increase compared to the previous research.
\end{abstract}

Keywords: Income smoothing; Listed firms; Vietnam.

\section{Introduction}

Firms often attempt to control fluctuations in reported earnings and steer them to levels which they consider desirable. Either managing reported figures to increase earnings when management thinks its initially planned term-end settlement targets (smoothing level figures) cannot be achieved or managing reported figures to decrease earnings when achievement of earnings higher than planned is certain may be implemented during a given fiscal period. This type of management accounting behavior is called income smoothing or income smoothing behavior. It has been noticed that income statement is considered as one of the statements to be presented in financial reporting. For that reason, the company's earning is considered vital information because it can be used to measure the corporate performance. In other words, information of the earning can be used to assess the performance or account- the ability of management and also predict the ability of companies in the effort of contributing to the following earning.

The managers will take action to increase earnings when earnings are relatively low and to decrease earnings when earnings are relatively high (Bao and Bao, 2004). Usually, the dampening in earnings variability is chosen by the management of the company to report a gradual growth in earnings that is in line with the private information of the management about future earnings. As income smoothing is widely accepted to be the most interesting type of earnings management.

Managers of companies will select different patterns or types of earnings management in different situations. Consequently, it is possible that over the course of several years managers can select different types of earnings management that they see fit for the economic situation in which the company is operating. Kirschenheiter and Melumad (2001) performed researches which showed that big bath accounting and income smoothing can be practiced together by the management of companies. The management 
of companies can perform big bath accounting in the current year and smooth the "saved" earnings over the future year earnings. Other combinations of types of earnings management are available. Income smoothing has received considerable attention in the academic literature in the past one hundred years (Kirschenheiter and Melumad, 2001). In an early discussion, Hepworth (1953) suggests that owners and creditors of an enterprise will feel more confident with corporate management that is able to report table earnings than the considerable fluctuation of reported earnings exists (Hepworth, 1953, p.34). Academics have basically investigated on: (1) whether firms do actually smooth income and which firms are more prompted to smooth (e.g.: DeFond and Park, 1997); (2) how income smoothing is implemented (e.g.: Beidleman, 1973), and (3) why managers are interested in smoothing income numbers (e.g.: Ronen and Sadan, 1981).

Within the financial accounting research topic of earnings management, researchers have always been very interested in studying income smoothing. Bao and Bao (2004) stated that in general the study of income smoothing has been very successful compared to the study of other forms of the use of earnings management. This success is due to a couple of reasons. First of all, researchers have been able to define income smoothing more precisely than other forms of earnings management. According to Bao and Bao (2004) research on the use of income smoothing has been successful because researchers have been able to identify which companies use income smoothing and which companies do not use income smoothing. This implies that there are methods which successfully measure the use of income smoothing.

However, some financial accounting research takes a different view on income smoothing and even concludes that a positive side is related to this type of earnings management. One of the more recent approaches to research income smoothing is presented by Tucker and Zarowin (2006). This article presents the use of income smoothing as being not necessarily bad. If the use of income smoothing improves, the earnings informativeness Tucker and Zarowin (2006) shed a new light on the discussion of the positive and the negative effects of the use of income smoothing. In the context of Vietnam, many studies have used these models for measuring earnings management. Hence, the author has tried to investigate income smoothing at listed companies on the Stock Exchange. The results of income smoothing help users of financial reporting to recognize that if smoothing earning is used and the Eckel index is a good tool to do that.

\section{Literature Review}

Within the financial accounting research topic of earnings management, academic researchers have always been very interested in studying the use of income smoothing. In general, academic research of income smoothing has been very successful compared to the study of other forms of the use of earnings management (Bao and Bao, 2004). Several reasons explain why academic research on income smoothing has been more successful than research on other types of earnings management. First of all, researchers have been able to define income smoothing more precisely than other forms of the use of earnings management. Some frequently used definitions of income smoothing are:

Beattie et al. (1994), "The reduction in earnings variability over a number of periods, or, within a single period, as a movement towards an expected level of reported earnings."

Fudenberg and Tirole (1995), "The process of manipulating the time profile of earnings reports to make the reported income 
stream less variable, while not increasing reported earnings over the long run."

Ronen and Sadan (1981), "An attempt by managers to manipulate income numbers so as to impart to the resulting series a desirable and smooth trend."

Based on these three definitions of income smoothing it is clear that to perform income smoothing, the management of a company will try to report an increasing linear stream of earnings over the years. To accomplish this, the management needs to increase earnings in periods of relatively low earnings and needs to decrease earnings in periods of relatively high earnings. If this is compared with the other types of earnings management, one could argue that in the period of relatively low earnings the management needs to perform earnings maximization while in periods of relative high earnings management needs to perform earnings minimization. The management of companies prefers to report a smooth stream of earnings because fluctuations in the profitability of the company are considered to have a negative effect on the company's risk profile (Hoogendoorn, 2004). Although this "misleading" of users of the financial statements at first appears to have a negative effect, positive effects of this type of earnings management exist.

Secondly, academic research has been successful in studying the use of income smoothing, because researchers have accomplished to make a clear differentiation between smoothers and non-smoothers. This implies that there are several tests which can successfully measure whether the management of a company practices income smoothing or not. Most empirical research has focused on export data of companies to determine the existence of income smoothing behavior (Albrecht and Richardson, 1990).

It is a fact that income smoothing becomes a phenomenon which has been often proved in some previous studies. This practice has been investigated through various levels of different samples. Furthermore, income smoothing is considered to be an important factor. Research by Moses (1987) and Atik \& Sensoy (2005) shows that at least $60 \%$ of the sample used in the study can be classified as smoothing the company earnings. Another proponent, such as Barnea et al. (1976) classified accounting income smoothing as inter-temporal smoothing and classification. Inter-temporal smoothing is based on the situation when cost and expenses are recognized and smoothing classification is done with the classification under ordinary cost and extraordinary one in which the ordinary post finally becomes flat.

Eckel (1981) distinguishes between income smoothing as a natural smoothing and intended smoothing. Natural smoothing is the alignment resulting from transactions that inherently produce a smoothed earning. In other words, the company's operations to generate income by collecting revenues and expenses are inherent to eliminate fluctuations in income flows. In other words, the process of generating income itself generates a stream of smoothed income. Alignment occurs without the intervention of any party. According to Eckel (1981), two main types of income smoothing exist. These are natural smooth income streams and intentionally smoothed income streams by the management of the company. These two main types of income smoothing streams are in addition recognized by Albrecht and Richardson (1990).

Although income smoothing is a type of earnings management that is deliberately performed by the management of companies, one type of income smoothing exists without the interference of management. Natural smooth income streams are the result of an earnings-generating process which is based 
on its own characteristics produces smooth income streams (Eckel, 1981). For example, public utility companies such as producers of energy or public transportation are expected to have natural smooth income streams. Consequently, the process of natural smoothing is not qualified as earnings management.

If the smooth income stream is qualified as intentionally being smoothed by the management of the company than earnings management is the basis for the reported smooth income stream. Within intentionally smoothed income stream, there are two subcategories. These are artificial smoothing and real smoothing.

Real income smoothing is the equivalent of earnings management by the use of real transactions. This type of income smoothing is sometimes also called transaction or economic smoothing (Stolowy and Breton, 2004). These transactions influence the cash flow of the company, which is not the case for artificial smoothing. One example of real transactions that can be applied to accomplish income smoothing is to select investment opportunities based on the covariance of the expected revenue series (Eckel, 1981).

Artificial smoothing or accounting smoothing is the equivalent of earnings management by the use of accounting choice or earnings management by means of financial accounting estimates. This type of smoothing does not include the use of an economic event. Instead, this type of income smoothing transfers revenues and expenses from one period to another period. One method for management to do this is the use of accruals. Consequently, much academic research on income smoothing has focused on accruals to measure income smoothing.

\section{Measuring Income Smoothing}

According to Copeland (1968), there are three research methods of the use of income smoothing. First, researchers can inquire management, second researchers can contact third parties such as auditors, and third researchers can perform studies on ex post data. The majority of the academic research has chosen the third option; performed studies based on ex post data. Early research on earnings management tried to detect earnings management by determining whether management of companies selected accounting methods and created certain provisions in such a manner to influence the income of the companies (Van der Bauwhede, 2003). This method often refers to as the classical approach (Albrecht, 1990). According to Eckel (1981), several down sides are related to this type of measuring the use of earnings management. First of all, these methods require a model to predict an expected and normalized income. It is very difficult to predict the expected normalized incomes for companies. Because this is very difficult, researchers could conclude that management of the company used income smoothing to manipulate the income of the company, while this was not the case. For example, some researchers used the income of the past year to predict the income of the current year. Consequently, income was differed from the expected normalized income due to another variable, research could conclude that the management of the company was practicing income smoothing. Moses (1987) states that these types of research approaches are not capable of differentiating between the natural smoothed income and the intentional smoothed income. Secondly, if researchers examine one income smoothing variable in relation to the normalized income they could get biased results. Consequently, researchers should study the effect of multiple income smoothing variables in relation to the normalized income. It will avoid the biased results. Thirdly, some academic researchers examined income smoothing variables in relation to the normalized income for one 
period. As income smoothing is a type of earnings management, that is only effective if the management of the company practices it for several years, academic research should examine several periods. Only if several periods are examined, researchers can conclusively determine if income smoothing is performed. In addition, Ronen and Sadan (1981) have also commented on these early approaches to the use of income smoothing. Their criticism is based on the fact that the early approaches are not capable of identifying motives for income smoothing and are no able to predict when income smoothing occurs.

\section{Income Variability Approach}

The first academic research approach to artificial income smoothing separate from natural smoothing was performed by Imhoff (1977). Imhoff was the first academic researcher to apply the income variability approach. According to Imhoff, the actions taken by the management of the company to perform "real" smoothing included in the sales figures of the company. The sales figures would, therefore, represent the "real" smoothing if this is performed by the management of the company. Consequently, by comparing the variance of sales to the variance of ordinary income the use of artificial income smoothing can by examined. The income variability approach defines a company as an income smoother if:

$$
\frac{C V_{\Delta I}}{C V_{\Delta S}} \leq 1
$$

Where $\Delta I=$ One period change in income

$\Delta S \quad=$ One period change in sales

$C V=$ Coefficient of variation

$$
=\frac{\sqrt{\text { Variance }}}{\text { ExpectedValue }}
$$

The income variability approach is additionally selected by Eckel (1981) and by Albrecht and Richardson (1990) to examine artificial income smoothing. The income variability approach is considered as a better approach than the classical approach. The classical approach tried to predict income and the income variability approach does not include any predictions of income. Additionally, the income variability approach examines sales and income for several periods. Although the income variability approach is an improvement on the classical approach, some downsides to this approach still exist. First, Eckel (1981) stated that the income variability approach is only capable of identifying the successful attempt by managing on the use of income smoothing. Unsuccessful attempts by management to perform income smoothing are not identified by this approach. Additionally, Albrecht and Richardson (1990) found that even if the ratio in the formula before is not below 1, the management of a company could still be performing artificial income smoothing. In addition, Michelson and et al. (1995) also apply the income variability approach for detecting the use of income smoothing.

\section{Data and results}

\subsection{Data}

According to above mentioned conditions, around 680 companies are members of statistical society in the current research. But, the respective number is obtained via limited society sampling formula.

According to Yamane (1967), overall is $\mathrm{N}=680$, the accuracy is $95 \%$, the standard error of $\pm 5 \%$.

$$
\mathrm{n}=\frac{\mathrm{N}}{1+\mathrm{N}(\mathrm{e})^{2}}=\frac{680}{1+680(0.05)^{2}}=251
$$

$\mathrm{n}$ - the sample size

$\mathrm{N}$ - the population size

$\mathrm{e}$ - the acceptable sampling error

In this study, the data panel includes 285 companies on Vietnam stock markets (HNX and HOSE) in the period of 2011 to 2015. Thus, the sample size represents the overall population. For some enterprises, data was collected from annual financial statement reports and a total observations of 1420 were 
collected. This time period was the longest that provided adequate data on the relevant variables and was also selected to allow a sufficient number of years to calculate the variables necessary to detect income smoothing or earnings management.

\subsection{Results}

This section will present the research results based on the empirical research performed to identify the smoothers and non- smoothers in the research data sample. The income variability method is applied to identify which companies are smoothers and which companies are-non smoothers. Consequently, if for a selected company is applicable, this company is identified as a smoother (Appendix A).

Selection mechanism of CL-FISH CORP as an instance of Income smoothing companies in net profit levels - is presented in Tables 1.

\section{Table 1}

Smoothing in net profit levels

\begin{tabular}{lrrrr}
\hline \multicolumn{1}{c}{ Year } & \multicolumn{1}{c}{ Net Profit } & Profit Variations & \multicolumn{1}{c}{ Sales } & $\begin{array}{c}\text { Sales } \\
\text { Variations }\end{array}$ \\
\hline 2011 & $114,883,000,000$ & $-1,288,041,000,000$ & \\
\hline 2012 & $15,279,000,000$ & $-99,604,000,000$ & $1,032,195,000,000$ & $-255,846,000,000$ \\
\hline 2013 & $5,148,000,000$ & $-10,131,000,000$ & $987,212,000,000$ & $-44,983,000,000$ \\
\hline 2014 & $12,312,000,000$ & $7,164,000,000$ & $854,490,000,000$ & $-132,722,000,000$ \\
\hline 2015 & $29,133,000,000$ & $16,821,000,000$ & $1,139,475,000,000$ & $284,985,000,000$ \\
\hline Sum & & $-85,750,000,000$ & $-148,566,000,000$ \\
\hline $\begin{array}{l}\text { Standard } \\
\text { deviation }\end{array}$ & $46,150,832,303$ & $200,495,798,849$ \\
\hline Mean & & $-21,437,500,000$ & $-37,141,500,000$ \\
\hline $\begin{array}{l}\text { Dispersion } \\
\text { Coefficient }(\text { CV })\end{array}$ & & -2.152808504 & $(5.398161056)$ \\
\hline $\begin{array}{l}\text { CY }= \\
\text { CVAI/CVAS }\end{array}$ & 0.398804052 & & \\
\hline
\end{tabular}

Since the respective index is smaller than 1. Therefore, it can be asserted that this company has smoothed in net profit level.
Selection mechanism of Bibica company as an instance of Income smoothing companies in net profit levels - is presented in Tables 2. 


\section{Table 2}

Non-smoothing in net profit levels

\begin{tabular}{lcccc}
\hline Year & Net Profit & Profit Variations & Sales & $\begin{array}{c}\text { Sales } \\
\text { Variations }\end{array}$ \\
\hline 2011 & $46,369,000,000$ & - & $3,287,083,000,000$ & - \\
\hline 2012 & $26,029,000,000$ & $-20,340,000,000$ & $3,516,336,000,000$ & $229,253,000,000$ \\
\hline 2013 & $44,880,000,000$ & $18,851,000,000$ & $3,728,692,000,000$ & $212,356,000,000$ \\
\hline 2014 & $57,793,000,000$ & $12,913,000,000$ & $4,333,945,000,000$ & $605,253,000,000$ \\
\hline 2015 & $85,815,000,000$ & $28,022,000,000$ & $4,153,080,000,000$ & $-180,865,000,000$ \\
\hline Sum & & $39,446,000,000$ & & $865,997,000,000$ \\
\hline Standard deviation & & $18,248,678,891$ & & $278,032,214,850$ \\
\hline Mean & & $9,861,500,000$ & & $216,499,250,000$ \\
\hline $\begin{array}{l}\text { Dispersion } \\
\text { Coefficient }(\text { CV })\end{array}$ & & 1.850497276 & & 1.284217912 \\
\hline CY $=$ CV $\Delta \mathrm{I} / \mathrm{CV} \Delta \mathrm{S}$ & 1.440952706 & & & \\
\hline
\end{tabular}

Since the respective index is larger than 1. Therefore, it can be asserted that this company has non-smoothed in net profit level.

\begin{tabular}{|c|c|c|}
\hline No. & Firm & Income smoothing index \\
\hline 1 & ABT & 0.887 \\
\hline 2 & ACL & 0.399 \\
\hline 3 & AGF & 1.264 \\
\hline 4 & ALT & -38.553 \\
\hline 5 & AMV & -1.733 \\
\hline 6 & ASM & 0.078 \\
\hline 7 & ASP & 12.524 \\
\hline 8 & B82 & -0.291 \\
\hline 9 & BBC & 1.441 \\
\hline 10 & BCC & 1.597 \\
\hline 11 & BCI & 0.79 \\
\hline 12 & BED & -1.302 \\
\hline 13 & BKC & 2.019 \\
\hline 14 & BLF & -1.022 \\
\hline 15 & BMC & 0.565 \\
\hline & & \\
\hline
\end{tabular}

The income smoothing index results from 285 listed companies in the 2011-2015 period.

\begin{tabular}{|c|c|c|}
\hline No. & Firm & Income smoothing index \\
\hline 144 & PGC & -0.181 \\
\hline 145 & PGD & -0.969 \\
\hline 146 & PGS & -0.105 \\
\hline 147 & PGT & 8.661 \\
\hline 148 & PHC & 25.652 \\
\hline 149 & PHR & 1.038 \\
\hline 150 & PIT & -0.94 \\
\hline 151 & PJC & -1.763 \\
\hline 152 & PJT & -0.149 \\
\hline 153 & PLC & 1.947 \\
\hline 154 & PMS & 1.514 \\
\hline 155 & PNC & 8.13 \\
\hline 156 & PNJ & 1.24 \\
\hline 157 & POT & 0.817 \\
\hline 158 & PPC & 5.97 \\
\hline & & \\
\hline
\end{tabular}




\begin{tabular}{|c|c|c|}
\hline No. & Firm & Income smoothing index \\
\hline 16 & BMP & 1.434 \\
\hline 17 & BPC & 0.07 \\
\hline 18 & BST & -9.212 \\
\hline 19 & BTP & -1.451 \\
\hline 20 & BTS & 2.663 \\
\hline 21 & $\mathrm{BXH}$ & -1.998 \\
\hline 22 & C92 & 0.851 \\
\hline 23 & CAN & 2.244 \\
\hline 24 & CAP & 2.322 \\
\hline 25 & $\mathrm{CCM}$ & -1.604 \\
\hline 26 & CII & 0.734 \\
\hline 27 & CJC & -0.874 \\
\hline 28 & CLC & 0.462 \\
\hline 29 & $\mathrm{CMC}$ & 7.909 \\
\hline 30 & $\mathrm{COM}$ & -0.277 \\
\hline 31 & CSC & 0.8 \\
\hline 32 & $\mathrm{CSM}$ & 1.851 \\
\hline 33 & CTC & 1.609 \\
\hline 34 & CTD & 1.116 \\
\hline 35 & CYC & -0.199 \\
\hline 36 & $\mathrm{D} 2 \mathrm{D}$ & 0.372 \\
\hline 37 & DAD & 1.753 \\
\hline 38 & $\mathrm{DBC}$ & 4.828 \\
\hline 39 & DC4 & -0.941 \\
\hline 40 & DCL & 0.186 \\
\hline 41 & DCS & -0.955 \\
\hline 42 & DHA & -1.352 \\
\hline 43 & $\mathrm{DHC}$ & 0.253 \\
\hline 44 & DHG & 1.14 \\
\hline 45 & $\mathrm{DHT}$ & 2.619 \\
\hline 46 & $\mathrm{DIC}$ & 8.901 \\
\hline 47 & DID & -0.194 \\
\hline
\end{tabular}

\begin{tabular}{|c|c|c|}
\hline No. & Firm & Income smoothing index \\
\hline 159 & PSC & -4.242 \\
\hline 160 & PTC & 5.009 \\
\hline 161 & PTL & 0.795 \\
\hline 162 & PV2 & 5.672 \\
\hline 163 & PVD & 0.928 \\
\hline 164 & PVE & -0.917 \\
\hline 165 & PVG & 0.783 \\
\hline 166 & PVI & -0.092 \\
\hline 167 & PVL & 12.708 \\
\hline 168 & PVR & -0.036 \\
\hline 169 & PVS & -1.056 \\
\hline 170 & PVT & 0.217 \\
\hline 171 & PVX & -4.473 \\
\hline 172 & PXI & 2.785 \\
\hline 173 & PXT & -37.598 \\
\hline 174 & QNC & 1.499 \\
\hline 175 & QST & -0.809 \\
\hline 176 & QTC & -1.142 \\
\hline 177 & RAL & 4.191 \\
\hline 178 & RDP & 2.952 \\
\hline 179 & REE & 1.873 \\
\hline 180 & RIC & 7.075 \\
\hline 181 & S55 & -0.54 \\
\hline 182 & S74 & -0.145 \\
\hline 183 & S99 & 0.243 \\
\hline 184 & SAF & 1.574 \\
\hline 185 & SAM & 1.918 \\
\hline 186 & SAV & -0.228 \\
\hline 187 & SC5 & 3.766 \\
\hline 188 & SCD & -0.784 \\
\hline 189 & SCJ & -0.24 \\
\hline 190 & SD5 & 5.246 \\
\hline
\end{tabular}




\begin{tabular}{|c|c|c|}
\hline No. & Firm & Income smoothing index \\
\hline 48 & DIG & 2.257 \\
\hline 49 & DMC & 0.071 \\
\hline 50 & DNP & 1.252 \\
\hline 51 & DPR & 0.888 \\
\hline 52 & DQC & 0.768 \\
\hline 53 & DST & 3.344 \\
\hline 54 & DTT & 0.4 \\
\hline 55 & DVP & 0.956 \\
\hline 56 & DXG & 0.623 \\
\hline 57 & DXV & 0.251 \\
\hline 58 & DZM & 2.674 \\
\hline 59 & EBS & -12.839 \\
\hline 60 & ECI & 0.662 \\
\hline 61 & FDC & -12.391 \\
\hline 62 & FMC & 0.718 \\
\hline 63 & FPT & 0.548 \\
\hline 64 & GDT & 2.999 \\
\hline 65 & GIL & 26.826 \\
\hline 66 & $\overline{G M C}$ & 1.764 \\
\hline 67 & GMD & 1.809 \\
\hline 68 & GTA & 0.187 \\
\hline 69 & HAD & 3.926 \\
\hline 70 & HAG & -2.124 \\
\hline 71 & HAP & 0.217 \\
\hline 72 & HAS & 1.248 \\
\hline 73 & HAX & 0.74 \\
\hline 74 & $\mathrm{HBC}$ & -2.33 \\
\hline 75 & $\mathrm{HCC}$ & 1.822 \\
\hline 76 & HCT & -2.311 \\
\hline 77 & HDC & -0.147 \\
\hline 78 & $\mathrm{HEV}$ & 1.648 \\
\hline 79 & HGM & 1.11 \\
\hline
\end{tabular}

\begin{tabular}{|c|c|c|}
\hline No. & Firm & Income smoothing index \\
\hline 191 & SD7 & 1.436 \\
\hline 192 & SD9 & 2.144 \\
\hline 193 & SDA & -2.721 \\
\hline 194 & SDC & 2.903 \\
\hline 195 & $\mathrm{SDH}$ & 1.83 \\
\hline 196 & SDN & 7.009 \\
\hline 197 & SED & 7.595 \\
\hline 198 & SFC & -0.568 \\
\hline 199 & SFI & 2.637 \\
\hline 200 & SFN & -0.218 \\
\hline 201 & SGD & -1.245 \\
\hline 202 & SGT & 3.466 \\
\hline 203 & SHI & 0.412 \\
\hline 204 & SHN & -0.366 \\
\hline 205 & $\overline{\text { SIC }}$ & 0.907 \\
\hline 206 & SJC & 0.81 \\
\hline 207 & SJE & 0.412 \\
\hline 208 & SJS & 1.193 \\
\hline 209 & $\overline{\mathrm{SMC}}$ & -0.553 \\
\hline 210 & SRC & -0.73 \\
\hline 211 & SRF & 3.891 \\
\hline 212 & ST8 & 0.682 \\
\hline 213 & STC & 2.445 \\
\hline 214 & $\overline{\mathrm{SVC}}$ & 1.872 \\
\hline 215 & SZL & 568.072 \\
\hline 216 & TAC & -0.748 \\
\hline 217 & $\mathrm{TBC}$ & 1.096 \\
\hline 218 & TBX & 0.475 \\
\hline 219 & $\mathrm{TCL}$ & 1.432 \\
\hline 220 & TCM & 15.147 \\
\hline 221 & TCR & -5.226 \\
\hline 222 & $\mathrm{TDH}$ & 1.021 \\
\hline
\end{tabular}




\begin{tabular}{|c|c|c|}
\hline No. & Firm & Income smoothing index \\
\hline 80 & $\mathrm{HHC}$ & 1.177 \\
\hline 81 & HJS & 3.161 \\
\hline 82 & HMC & 1.342 \\
\hline 83 & $\mathrm{HOM}$ & -5.507 \\
\hline 84 & HPG & 0.95 \\
\hline 85 & HRC & 0.939 \\
\hline 86 & HSG & 1.111 \\
\hline 87 & HST & -41.34 \\
\hline 88 & HT1 & 2.408 \\
\hline 89 & HTP & 5.64 \\
\hline 90 & HTV & 4.031 \\
\hline 91 & HUT & 2.854 \\
\hline 92 & $\mathrm{HVG}$ & -7.746 \\
\hline 93 & HVT & 5.371 \\
\hline 94 & $\mathrm{ICF}$ & 0.746 \\
\hline 95 & IMP & 9.158 \\
\hline 96 & ITA & 0.846 \\
\hline 97 & ITC & 0.405 \\
\hline 98 & $\mathrm{KBC}$ & 1.532 \\
\hline 99 & KDC & -0.436 \\
\hline 100 & KHA & 0.682 \\
\hline 101 & KHP & 16.98 \\
\hline 102 & $\mathrm{KKC}$ & -1.48 \\
\hline 103 & KMR & 3.231 \\
\hline 104 & KMT & -1.26 \\
\hline 105 & $\mathrm{KSB}$ & 14.378 \\
\hline 106 & $\mathrm{KSH}$ & 2.672 \\
\hline 107 & KSS & 0.897 \\
\hline 108 & L10 & 1.333 \\
\hline 109 & L18 & -1.12 \\
\hline 110 & L43 & 0.567 \\
\hline 111 & L44 & 1.221 \\
\hline
\end{tabular}

\begin{tabular}{|c|c|c|}
\hline No. & Firm & Income smoothing index \\
\hline 223 & THB & -5.458 \\
\hline 224 & TIC & 0.843 \\
\hline 225 & TIE & 1.111 \\
\hline 226 & TIX & 2.157 \\
\hline 227 & TJC & 0.031 \\
\hline 228 & $\mathrm{TKC}$ & 3.952 \\
\hline 229 & TKU & -1.103 \\
\hline 230 & TMP & 0.497 \\
\hline 231 & TMS & 0.962 \\
\hline 232 & TMX & 0.818 \\
\hline 233 & TNA & 2.608 \\
\hline 234 & $\mathrm{TNC}$ & 0.332 \\
\hline 235 & TNG & 1.461 \\
\hline 236 & TPC & 0.053 \\
\hline 237 & TRA & 1.281 \\
\hline 238 & TRC & 1.031 \\
\hline 239 & TS4 & -0.391 \\
\hline 240 & TSC & -1.32 \\
\hline 241 & TST & -2.35 \\
\hline 242 & TTF & -0.082 \\
\hline 243 & TV2 & 1.256 \\
\hline 244 & TV3 & -0.776 \\
\hline 245 & TXM & -0.803 \\
\hline 246 & TYA & 0.092 \\
\hline 247 & UIC & 1.222 \\
\hline 248 & $\mathrm{VBH}$ & 0.695 \\
\hline 249 & VC1 & 1.107 \\
\hline 250 & VC2 & 0.561 \\
\hline 251 & VC6 & -0.024 \\
\hline 252 & VC7 & -1.584 \\
\hline 253 & VCC & 0.75 \\
\hline 254 & VCG & -2.492 \\
\hline
\end{tabular}




\begin{tabular}{|c|c|c|}
\hline No. & Firm & Income smoothing index \\
\hline 112 & L61 & -35.397 \\
\hline 113 & LAF & -1.159 \\
\hline 114 & LBE & 0.179 \\
\hline 115 & LBM & 1.181 \\
\hline 116 & $\mathrm{LCG}$ & 1.114 \\
\hline 117 & LGC & 0.892 \\
\hline 118 & LGL & -18.294 \\
\hline 119 & LHG & 2.574 \\
\hline 120 & LTC & 38.404 \\
\hline 121 & LUT & -0.112 \\
\hline 122 & MAC & 0.699 \\
\hline 123 & MCG & -12.312 \\
\hline 124 & $\mathrm{MCO}$ & 1.603 \\
\hline 125 & $\mathrm{MCP}$ & -0.121 \\
\hline 126 & $\mathrm{MHC}$ & -0.352 \\
\hline 127 & MKV & 3.714 \\
\hline 128 & $\mathrm{MSN}$ & 98.734 \\
\hline 129 & NAV & 0.153 \\
\hline 130 & NBB & 7.929 \\
\hline 131 & $\mathrm{NBP}$ & 0.555 \\
\hline 132 & NGC & -0.083 \\
\hline 133 & $\mathrm{NSC}$ & 0.418 \\
\hline 134 & NST & -0.745 \\
\hline 135 & NTL & 2.943 \\
\hline 136 & NTP & 11.076 \\
\hline 137 & $\mathrm{OCH}$ & -58.456 \\
\hline 138 & OGC & -1.586 \\
\hline 139 & ONE & 3.423 \\
\hline 140 & $\mathrm{OPC}$ & 1.985 \\
\hline 141 & PAC & -3.755 \\
\hline 142 & PDC & 2.825 \\
\hline 143 & PET & -0.228 \\
\hline
\end{tabular}

\begin{tabular}{|c|c|c|}
\hline No. & Firm & Income smoothing index \\
\hline 255 & VCS & 2.418 \\
\hline 256 & VDL & 0.422 \\
\hline 257 & VE1 & 1.404 \\
\hline 258 & VE9 & 2.97 \\
\hline 259 & VFG & 1.277 \\
\hline 260 & VGS & 0.296 \\
\hline 261 & VHC & -11.745 \\
\hline 262 & VHG & 1.532 \\
\hline 263 & VIC & 81.575 \\
\hline 264 & VID & -5.841 \\
\hline 265 & VIP & 300.285 \\
\hline 266 & VIS & 1.201 \\
\hline 267 & VMC & 2.307 \\
\hline 268 & VNA & 2.904 \\
\hline 269 & VNC & 12.177 \\
\hline 270 & VNE & 3.016 \\
\hline 271 & VNG & -2.294 \\
\hline 272 & VNL & 11.719 \\
\hline 273 & VNM & 2.357 \\
\hline 274 & VNS & 1.666 \\
\hline 275 & VNT & 2.623 \\
\hline 276 & $\mathrm{VPH}$ & 0.477 \\
\hline 277 & VPK & -3.737 \\
\hline 278 & VSC & 0.856 \\
\hline 279 & VSH & -0.073 \\
\hline 280 & VTB & -3.363 \\
\hline 281 & VTC & 0.475 \\
\hline 282 & VTL & -0.174 \\
\hline 283 & VTO & 3.97 \\
\hline 284 & VTS & 1.52 \\
\hline 285 & VTV & 0.301 \\
\hline
\end{tabular}


The companies will be regarded as profit smoothers if they smooth their profit in one of the net profit levels, the respective company is an income-smoothing organization because its $\mathrm{CV}$ ratios are all below 1. The objective of this model is specifically synthetic smoothing of profit. Natural income smoothing is not essentially related to any managerial action or decision.

Furthermore, actual income smoothing also represents an economic situation which is not analyzed in the scope of the current research. But on the contrary, synthetic smoothing is, in fact, indicative of intentional actions of the management for smoothing time series of reported profits, which evidently leads to deviation in the provision of economic facts. Another issue needed to be emphasized is the fact that Eckel's theoretical framework is merely used for identifying successful efforts of profit-smoothing. In other words, this model will not be able to identify those organizations which failed to smooth their profit.

\section{Conclusion}

In this study, the income variability is a proven method to test the use of income smoothing and is additionally applied by Eckel (1981) and Albrecht and Richardson (1990) amongst others. For the period of 2011 to 2015,111 companies are identified as smoothers and 174 companies are identified as non-smoothers based on the income variability approach. However, this period includes the years of the financial crisis. Consequently, this research has successfully identified companies as smoothers and nonsmoothers.

According to Eckel (1981), natural smooth income streams and intentionally smoothed income streams exist. Intentionally smoothed income streams are the focus of this research as these income streams are the results of the use of earnings management by the management of the company. To apply income smoothing, the management of the company needs to consider the smoothing objects, dimensions, and instruments as defined by Barnea, Ronen and Sadan (1976) and Copeland (1968). Although most prior empirical research has qualified income smoothing as a bad phenomenon, this research comments on a possible good characteristic. If income smoothing is applied by the management of the company to signal their private information about future earnings to the users of the financial statements, the use of income smoothing can be qualified as a positive one. However, several motives are not related to the signaling of private information.

\section{Limitation and suggestions for future research}

This is either a limitation of the model applied to measure the use of income smoothing, or is related to the smoothing behavior of the management of the companies in times of crisis. As this is beyond the scope of this research, it is qualified as a research limitation. Second, a research limitation is related to the variables applied in this research. This research selected the net income of the companies as the smoothing object. This selection was made because the net income is the most studied smoothing object. Consequently, it is possible that other smoothing objects will result in other identifications of smoothers and non-smoothers.

Based on the empirical research, several suggestions for future academic research on the relation of income smoothing and the earnings informativeness can be defined. It is concluded from the empirical research, a change in the research period influenced the results of which companies are identified as smoothers and which companies are identified as non-smoothers by the income variability model. This research concludes that the financial crisis could be responsible for the change in the identification of smoothers and 
non-smoothers. Future academic research could additionally comment on if the financial crisis affected the use of income smoothing by the management of the companies.
Additionally, the power of the income variability model to measure income smoothing in times of economic distress could be investigated by future academic research

\section{References}

Albrecht, W.D., and F.M. Richardson (1990). Income smoothing by economy sector. Journal of Business Finance \& Accounting, 17(5), 713-730.

Bao, B.H. and D.H. Bao (2004). Income Smoothing, Earnings Quality and Firm Valuation. Journal of Business Finance \& Accounting, 31(9)\&(10) (November/December). Journal of Business Finance \& Accounting, 21(6), 791-811.

Beattie, V., S. Brown, D. Ewers, B. John, S. Manson, D. Thomas and M. Turner. (September 1994). Extraordinary items and income smoothing: A positive accounting approach. Journal of Business Finance and Accounting, 21(6), 791-811.

Copeland, R.M. (1968). Income smoothing. Empirical Research in Accounting, Selected Studies (Supplement), 6, 101-116.

Davoud, P. \& Bita, M. (2008). Analyzing relationship between financial ratios and Stock returnfor income Smoothing and non-smoothing companies, separately. Quarterly of Financial Researches, 24, 81-98.

DeFond, M., C.W. Park (1997). Smoothing income in anticipation of future earnings. Journal of Accounting and Economics, 23, 115-139.

Demski, J. S. (1998). Performance measure manipulation. Contemporary Accounting

Eckel, N. 1981. The income smoothing hypothesis revisited. Abacus, 17(1), 28-40.

Fundenberg, D. \& Tirole, J. (1995). A theory of income and dividend smoothing based on incumbency rents. Journal of Political Economy, 103(1), 75-93.

Godfrey, J.M. and K.L. Jones (1999). Political cost influences on income smoothing via extraordinary item classification. Accounting and Finance, 39(3), 229-254.

Goel, A. M. \& Thakor, A. V. (2003). Why Do Firms Smooth Earnings? University of Michigan. Journal of Business, 76(1).

Gordon, M. J. (1964). Postulates, principles and research in accounting. The Accounting.

Hepworth S.R. (January 1953). Smoothing periodic income. The Accounting Review, 32-39.

Hoogendoorn, M.N., Klaassen, J., Krens, F. (redactie) 2004. Externe verslaggeving in theorie en praktijk, vierde druk. Elsevier, 2004, 2 delen.

Imhoff, E.A. (1977). Income smoothing, a case for doubt. Accounting Journal, 85-100.

Kirschenheiter, M, N.D. Melumad (2002). Can big bath and earnings smoothing co-exist as equilibrium financial reporting strategies? Journal of Accounting Research, 4(3), 761-796.

Michelson, S.E., J. Jordan-Wagner, C.W. Wootten (1995). A market based analysis of income smoothing. Journal of Business Finance \& Accounting, 22(8), 1179-1193.

Moses, O.D. (1987). Income smoothing and incentives: Empirical tests using accounting changes. The Accounting Review, 62(2), 358-377.

Nejad, H. S., Zeynali, S., \& Alavi, S. S. (2013). Investigation of income smoothing at the companieslistedonthestock exchange by the using index eckel (case study: tehran stock exchange). Idea, 2(2).

Norm, E. (1981). The income smoothing Hypothesis revisited, ABACUS, 14(1). 
Ronen, J., S. Sadan (1981). Smoothing income numbers, Objectives, Means, and Implications. Reading, MA, Addison Wesley.

Ronen, J., V. Yaari (2008). Earnings management: emerging insights in theory, practice and research series. Springer series in accounting scholarship.

Stolowy, H., G. Breton (2004). Accounts manipulation: a literature review and proposed conceptual framework, Review of Accounting \& Finance, 3(1), 5-66.

Tucker, J.W., P.A. Zarowin (2006). Does income smoothing improve earnings informativeness?, The Accounting Review, 81(1), 251-270.

Trueman, B. and S. Titman (1988). An explanation for accounting income smoothing. Journal of Accounting Research (Supplement), 26, 127-139.

Yamane, T. (1967). Elementary sampling theory. Englewood Cliffs, N.J.: Prentice-Hall. 